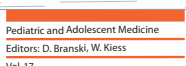

Controversies in Pediatric and Adolescent Hematology Editors
A.E.Thomas C. Halsey

KARGER

\section{Controversies in Pediatric and Adolescent Hematology}

\section{Editor}

\section{Angela E. Thomas, Christina Halsey}

Hematological disorders in children and adolescents pose a wide range of management challenges and treatment dilemmas.

In this book an internationally acclaimed panel of authors, each chosen for expertise in their field, have produced a stateof-the-art collection of review articles focusing on the very latest advances and controversies in the management of pediatric and adolescent hematological problems. The whole range of benign and malignant, congenital and acquired, acute and chronic conditions is discussed in detail. Individual chapters cover hematologic problems on the pediatric intensive care unit, treatments for iron deficiency and ITP; advances in stem cell transplantation, gene therapy, novel pharmaceutics and molecular diagnostics, as well as transition from child to adult are also explored.

Providing an up-to-date look at both specific hematologic disorders in the pediatric and adolescent population and also hematologic problems that arise in association with systemic disease, this book is essential reading not only for pediatric and adult hematologists but also for pediatricians, pediatric or hematologic specialist nurse practitioners and pediatric pharmacologists.

Fields of Interest:

Fields of Interest: Pediatrics; Hematology; Intensive Care, Leukemia, Neonatology, Nursing, Oncology

\section{Contents}

Preface: Thomas, A.E.; Halsey, C.

Neonatal Thrombocytopenia: Chakravorty, S.; Roberts, I. Pediatric and Adolescent Immune Thrombocytopenia: Prevention of Bleeding versus Burden of Treatment: Cooper, $N$.

Thrombosis in Paediatrics: Genetic versus Environmental Risk Factors and Implications for Management: Monagle, $P$.

Hematological Problems in Pediatric Intensive Care: Revel-Vilk, S.; Cox, P.; Robitaille, N.; Blanchette, V. New Advances in the Treatment of Children with Hemophilia: Lillicrap, D.

Myelodysplastic and Myeloproliferative Diseases in Children: Current Concepts: Vyas, $P$.

Towards Personalized Medicine in Childhood Acute Lymphoblastic Leukaemia: Halsey, C.

Reduced Intensity Conditioning in Paediatric Haematopoietic Cell Transplantation: Chiesa, $R_{\text {。i }}$ Veys, $P$.

Can Iron Chelators Replace Stem Cell Transplantation in the Treatment of Thalassaemia Syndromes?: Darbyshire, P.J.

Iron Deficiency: When and Why Oral Iron May Not Be Enough: Crary, S.E.; Buchanan, G.R.

Principles of Transitional Care in Haematology: Bolton-Maggs, $P_{\text {.; }}$ Choudhuri, S.

Author Index

Subject Index

\section{www.karger.com/pamed}

Pediatric and Adolescent Medicine, Vol. 17

Controversies in Pediatric and

Adolescent Hematology

Editors: Thomas, A.E. (Edinburgh); Halsey, C. (Glasgow)

VIII + 178 p., 14 fig., 19 tab., 2014

CHF 148.- / EUR 123.- / USD 174.00 (hard cover)

CHF 178.- / EUR 148.- / USD 209.00 (online)

Online version for institutional purchase

Prices subject to change

EUR price for Germany,

USD price for USA and Latin America only ISBN 978-3-318-02422-7 (hard cover)

e-ISBN 978-3-318-02423-4 
The books series

\section{A problem-oriented series for both the general practitioner} and the hospital physician

\section{Pediatric and Adolescent Medicine}

Series Editor: Kiess, W. (Leipzig)

ISSN 1017-5989 / e-ISSN 1662-3886

This series deals with rapidly evolving pediatric subspecialties such as perinatal medicine, pediatric endocrinology, immunology, neurology and cardiology. The individual volumes not only highlight recent advances in a particular area, but also provide a comprehensive overview of new trends in monitoring child development and subsequent adult health. The series aims to inform both the general practitioner and the hospital physician about current theoretical and practical developments in pediatric and adolescent medicine.

Online version for institutional purchase

Prices subject to change

EUR price for Germany, USD price for USA and Latin America only

\section{www.karger.com/pamed}

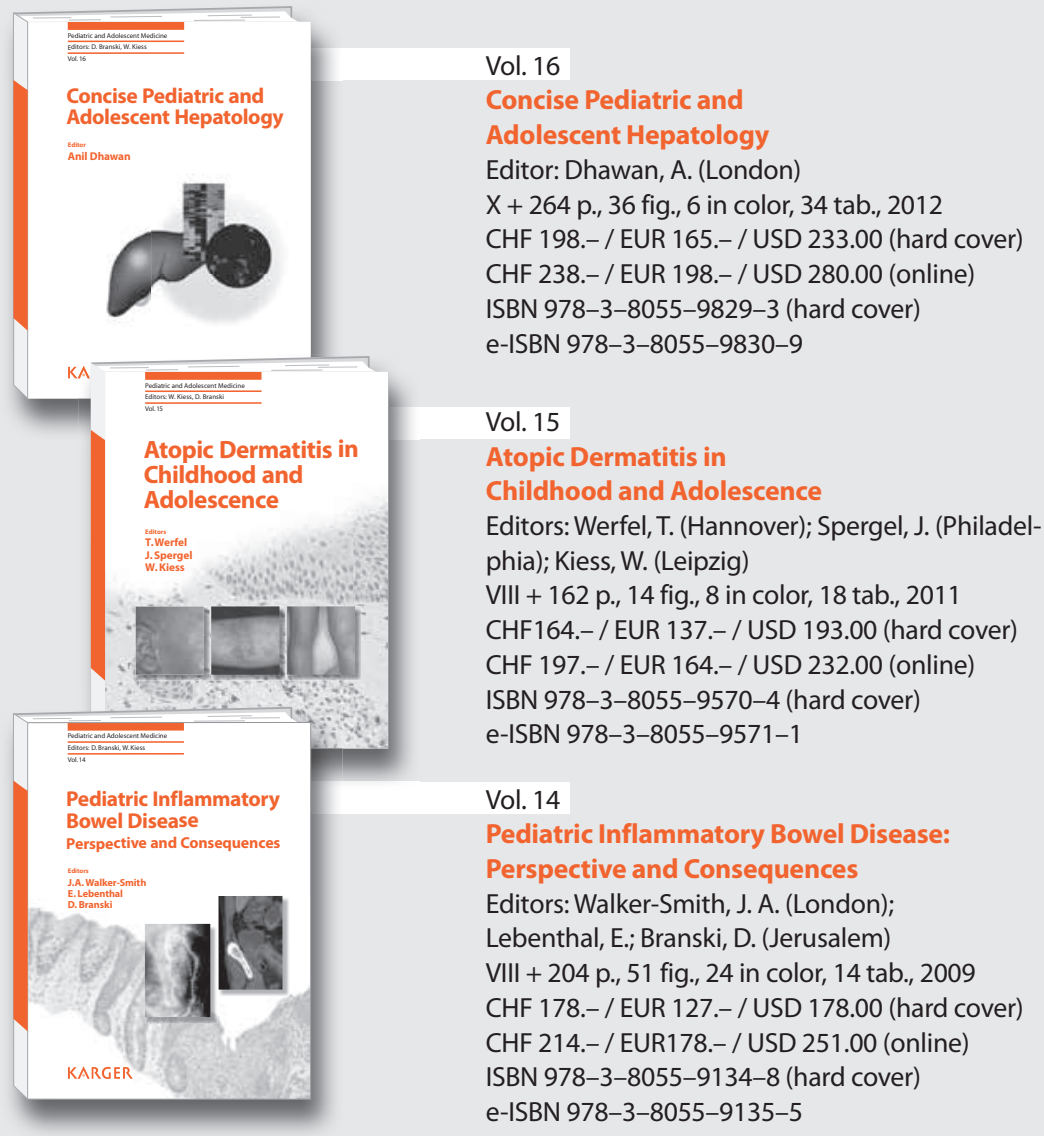

Vol. 1-13 available, please ask for details
Order Form

Pediatric and Asolescent Medicine

\section{Please send:}

_copy/ies: Vol. 17: Controversis in Pediatric and Adolescent Hematology

CHF 148.- / EUR 123.- / USD 174.00

ISBN 978-3-318-02422-7

_copy/ies: Vol. 16: Concise Pediatric and Adolescent Hepatology

CHF 198.- / EUR 165.- / USD 233.00

ISBN 978-3-8055-9829-3

_copy/ies: Vol. 15: Atopic Dermatitis in Childhood and Adolescence

CHF164.- / EUR 137.- / USD 193.00

ISBN 978-3-8055-9570-4

_copy/ies: Vol. 14: Pediatric Inflammatory Bowel Disease: Perspective and Consequences

CHF 178.- / EUR 127.- / USD 178.00

ISBN 978-3-8055-9134-8

_ copy/ies:

ISBN 978-3-318-

$\square$ the book series

Pediatric and Adolescent Medicine on continuation beginning with vol.

$\square$ information on vols

All Karger series are available on continuation. Each volume will be sent upon publication until order is countermanded.

For easy ordering or further information about the series log on to: www.karger.com/pamed

Payment

(Postage and handling included with prepayment)

Charge this order to my credit card

$\square$ American Express $\quad \square$ Diners

$\square$ Visa $\quad \square$ Euro-, MasterCard

Card No.

Exp. date:

CVV / CVC

3 digits in the signature field on the back of

Visa and MasterCard)

$\square$ Check enclosed $\quad \square$ Please bill me

Name/Address (please print):

E-Mail

Date

Signature

Orders can be placed at agencies, bookstores, directly with the publisher, or with any Karger distributor.

S. Karger AG, P.O. Box, 4009 Basel (Switzerland) f: +4161306 12 34, e: orders@karger.com

USA: S. Karger Publishers, Inc., 26 West Avon Road, P.O. Box 529

Unionville, CT 06085 (USA), Toll free: +1-800-828-5479

Germany: S. Karger $\mathrm{GmbH}$, 79095 Freiburg

France: Enter \& Read, Albertine Luginbuhl, 75007 Paris

Japan: Karger Japan, Inc., Tokyo 105-0012

South East Asia, China and Taiwan: Karger Regional Office, Kuala Lumpur 50470 (Malaysia) 